\title{
WHAT AFFECTS THE IMPLEMENTATION AND REALISATION OF STRATEGY IN ORGANISATIONS? \\ Viktors Hiršsons ${ }^{1}$, Iveta Ludviga ${ }^{2}$
}

\begin{abstract}
In today's changing environment companies are pushed to be flexible, develop new strategies and implement change plans. Strategy implementation and realisation is a critical component of organizational performance, however, many organizations fail to implement their strategic plans, while others could not achieve their desired results. In practice nowadays more attention is paid to the implementation of the strategy than to its creation, still strategy research most often treats strategy execution and realisation as a black box. The aim of this study is to find out the factors influencing the successful implementation and realization of business strategy in Latvian organizations. Quantitative research using a structured questionnaire $(\mathrm{n}=440)$ and a multivariate linear regression analysis shows that managerial competence and leadership followed by clarity of goals play a decisive role in the successful implementation of business strategy. Implications of the results for managerial practice are discussed and propositions for future research provided.
\end{abstract}

JEL Classification Numbers: M10; M19, DOI: https://doi.org/10.12955/peb.v1.25

Keywords: strategy, implementation, realization, Latvia

\section{Introduction}

A primary research question of strategic management is related to understanding why some firms are more successful and perform better than others and (Greer et al., 2017; Pfarrer et al., 2019). The modern business environment is becoming more and more unpredictable and this applies to global competition, rapidly changing technologies, and even societies. Previously unknown organizations appear on the market, but other well-known firms disappear simply because they fail to react to changes in the external environment (Caune \& Dzedons, 2009). Every organization faces the need to change their strategy. Obeidat and colleagues (2017) believe that the existing business environment has become much more uncertain and unpredictable for profit and non-profit organizations., therefore, managers and leaders of different types of organizations need to think, learn and act strategically (Obeidat et al., 2016).

An organization strategy is a plan that describes how to achieve organizational goals, how to run an organization, how to position itself in the market, attract customers, compete successfully and win the competition. The strategy traditionally is aimed at securing a long-term competitive position and good financial performance (Dess et al., 2012). Developing and launching a successful strategy is a very difficult task for any organization and even the best-formulated strategies may fail to deliver their desired outcome for the firm if they are not successfully implemented (Noble, 1999). The strategy implementation and realisation appear to be even more important than its creation. A review of published literature indicated that many organizations had failed to implement more than $70 \%$ of their new strategic plans, while 30\% could not achieve anything at all (Miller, 1997). Charan and Colvin (1999) observed that 9 out of 10 organizations were unable to implement their strategic plans for several reasons. Therefore, nowadays more attention is paid to the implementation of the strategy.

Frequently the key to not achieving strategic goals is that leaders do not invest as much time, energy, and resources in implementing the strategy as in formulating the strategy (Bolboli \& Reiche, 2013). They do not realize that implementing a strategy requires well-organized strategy realisation processes and that they need to go beyond the business process routine to do so.

Therefore, in order to increase the likelihood of successful strategy implementation, it is necessary to identify and analyse the most important and effective factors that influence strategy implementation and realisation within the organization. Several researchers have tried to determine the most important factors for successful strategy implementation, but most of the previous research has focused on the first phase of the strategic decision-making process. There is a limited body of research describing the strategy implementation process and the factors that directly influence strategy implementation. The aim of this study is to determine the most important factors for successful strategy implementation in Latvian business companies.

The article is structured as follows. The first section is devoted to the analysis of literature and publications on the strategy implementation process and factors which affect it and leads to the

\footnotetext{
${ }^{1}$ RISEBA University of Applied sciences, Riga, Latvia, v.hirssons@inbox.lv

${ }^{2}$ RISEBA University of Applied sciences, Riga, Latvia, iveta.ludviga@ riseba.lv
} 
development of five hypotheses. Further the research methodology is described and followed by analysis and discussion. The study concludes with the limitations of the study and provides recommendations for future research.

\section{Theory and hypotheses}

Strategy is a plan or sketch that integrates the organization's main objectives, policies and activities into a coherent set. A well-formulated strategy enables the organization's always limited resources to be organized and distributed efficiently, based on the internal competencies, anticipated changes in the external environment, and potential competitor activities (Mintzberg et al., 2002).

However, it is not the strategy formulation, but strategy implementation which is widely considered to provide the greatest challenges for top executives (Greer et al., 2017; Hrebiniak, 2006). Thomson and Strickland explain strategy implementation as the transformation of strategy into a plan of concrete actions and later into results (Dess et. al., 2012). Strategy Implementation converts strategy into actions, it refers to the execution of the plans to achieve the objectives and accomplish the long-term goals of the organization.

Okumus (2003) identifies 11 factors that influence strategy implementation: strategy development, environmental uncertainty, organizational structure, organizational culture, leadership, operational planning, resource availability, communication, people, control and output. Several researchers have grouped these factors into different groups: context, process, and outcomes (Bryson \& Bromiley, 1993); planning and design (Hrebniak \& Joyce, 1984); realizers and tools for realization (Miller, 1997); content, context and action (Dawson, 1997); content, context, process and outcomes (Okumus, 2001); structure and process components (Skivington \& Daft, 1991); context and process (Schmelzer \& Ohlsen, 1994); contextual, system and action levers (Miller \& Dess, 1996).

Okumus (2003) has grouped these eleven strategy influencing factors into four categories:1) strategic content (which includes strategy development and strategic aims); 2) strategic context (further divided into internal and external - internal context includes organizational structure, culture and leadership, while external context includes environmental uncertainty); 3) operational process (which includes operational planning, resource availability, people, communication and control); 4) results (which includes the results of the strategy implementation).

Following Okumus (2003), this study analyses the factors influencing strategy implementation from each of the four groups: strategy and goal clarity (strategic content), change process, managerial competence and leadership (strategic context), employee attitude and communication (operational) process) and strategy implementation (results). These factors will be analysed in more detail below.

Dobni and colleagues explain that strategy is nothing more than simple rules to be different (Dobni et al., 2016). Still the competitive advantage of organizations having such rules is frequently counteracted by competitors with advanced dynamic skills and adaptability of strategy. This happens because the employees of the organization do not have a clear understanding of the objectives and strategic aims. There is a clear need to understand whether strategic frameworks are based on position, leverage or approach and need to focus on delivering what is intended (Dobni et al., 2016). Similarly, Parnell (2010) states that strategic aim clarity is directly linked to the performance of the organization. Parnell demonstrates the close link between strategy comprehension and strategy implementation. His study shows that organizations with greater clarity of strategy and goals outperformed organizations with unclear strategies and goals (Parnell, 2010). Moreover, Kruger \& Mama (2012) conclude that the clarity of strategy and goals, which can be considered as an element of identity management, should be considered as part of the strategy. Identity management implementation consists of a strategic thinking process that is accompanied by tactical implementation.

Based on the above discussion, it can be argued that the clarity of the strategy, the aims and the objectives have an impact on strategy implementation, Thus, this leads to the Hypothesis 1: The clarity of organisational aims has a positive impact on strategy implementation and realisation.

The implementation of any strategy involves managing certain changes to achieve the desired state of affairs in the implementation of the developed strategy. As with any process in an organization, strategic change must be driven (Caune \& Dzedon, 2009). Edmonds (2011) argues that a properly planned and accomplished process of change implementation can achieve good results, namely, the achievement of 
set goals and financial results. Similarly, Lettwattanapongchai and Swierczek (2014) prove that a successfully managed change process has a positive impact on business performance and employee satisfaction. Therefore, Hypothesis 2: The organisations ability to manage change has a positive impact on strategy realisation.

Johnson and colleagues (2014) explain that strategy is based on organizational competencies and capabilities, which in turn depend on people. Thus, the realization of an organizational strategy requires the existence of certain types of employees - engaged employees. Providing the necessary number of specialists will help the company to better execute its strategy, however, without employee engagement, organizational results will not be achieved. Thompson and Strolled (2003) indicate that organizations have both tangible and intangible resources (resources and skills) that create a competitive advantage for the company. As one of the elements of intangible resources, the authors mention the culture of the organization and the system of stimulation (or motivation). This system consists of the employees' trust in the company ideals and satisfaction.

Strategy implementation will definitely be influenced by how much the employee will be interested in taking on new responsibilities and engaging in change and new strategy. Kohtamaki and colleagues (2012) found that employee engagement in strategic planning has a positive impact on commitment to strategy, thereby increasing company performance. Ludviga and Kalvina (2016) confirmed a significant link between job satisfaction and work engagement - satisfied employees are also more engaged. Yin (2018) argues that satisfaction engagement has a positive impact on task performance and organizational citizenship, which undoubtedly has a positive impact on company performance. Similarly, Sparrow (2013) explains that employees who engage in company processes ensure the long-term preservation of the company's value. This leads to the Hypothesis 3: Employee job satisfaction has a positive impact on strategy realisation.

As organizations get bigger and more complex, managers need to be aware of the importance of coordinating actions to implement a successful strategy (Obeidat et al., 2017). In several studies, researchers argue that communication is one of the most important factors for successful strategy implementation. For example, Schaap (2012) emphasizes the importance of communication in strategy realisation. Obeidat and colleagues (2017) explain that communication includes the following elements: a clear explanation of new responsibilities and tasks, why processes need to be changed, what strategic decisions must be made first. Peng and Littlejohn (2001) summarize that effective communication is a key requirement for effective strategy implementation, however, it does not guarantee effective strategy implementation. Failure is practically inevitable when communication is inadequate (Anon., 2018). Effective top-down communication and vice versa make it possible to increase support for any new strategy and to solve problems more easily. Similarly, Ikavalko (2002) explain that there is a strong link between organization of communication and communication problems. It is clear from their research that middle managers are usually responsible for ensuring the continuity of the strategy's communication flow, and middle managers are also responsible for ensuring that the strategy is understood. The researchers confirm the conclusion of Peng and Littldong (2001) that successful communication does not yet guarantee successful strategy implementation. However, Altonen and Ikavalko (2002) point out that understanding the problems the communication which can arise in the course of everyday strategic decision-making will prevent form failures in strategy implementation. Thus, the following hypothesis is developed. Hypothesis 4: Communication within the organisation has a positive impact on strategy realisation

Much of the research on strategy implementation among other factors has focused on strategic leadership (Greer et al., 2017). Numerous studies show that managerial competence and leadership play a vital role in strategy implementation (e.g. Mintzberg et al., 2002). Katsioloudes (2006) considers managerial leadership as a major factor influencing strategy implementation since leaders are the ones who can transform organizations. Thomson and Strickland (2003) argue that the role of the manager is to translate the strategic plan into concrete actions that will help achieve the stated goals. They point out that one of the key tasks of strategy implementation is the development of an internal leadership system. Many researchers confirm the role of managers in strategy implementation including (e.g. Maditinos et al., 2014; Schaap, 2012; Hazarbassanova, 2016; Okumus, 2003). Based on the discussions in this subsection, it can be concluded that managerial competence and leadership are important in the context of strategy implementation. Hypothesis 5: Leadership has a positive impact on strategy realisation. 


\section{Methodology}

The research is quantitative in nature and the questionnaire was prepared by the authors considering the key hypothesised factors which may impact strategy implementation.

The dependent variable of this research is strategy implementation and realisation. It is measured with thirteen statements each of which is measuring one aspect indicating that the strategy has been realised successfully. Respondents were asked to evaluate whether their perception of an organisation`s performance related to strategy realisation, for example, they had to express their agreement or disagreement to such statements as 'My organisation knows its strategic alternatives' and 'My organisation achieves the set aims'.

Independent variables are the hypothesised factors which have an impact on strategy implementation. The aim clarity include six statements measuring whether an employee has a clear understanding of an organisation's mission, vision, values, aims, strategy and other guidelines. A sample statement is 'I clearly understand my organisations strategic aims'. Change management measures respondent's perception about change management processes in the organisation with six items, for example 'Change management processes in my organisation are well planned'. Job satisfaction refers to the level of respondents` satisfaction with nine aspects of a job. A sample statements are 'I am satisfied with my job environment' and 'I am satisfied with the internal climate in my organisation'. Communication measures an employee's perception of communication processes within the organisation, for example, 'In my organisation, it is easy to communicate with all levels of employees'. The Leadership variable with nine statements measures aspects of effective leadership, like 'My organisations manager(s) is charismatic' and 'My organisations manager(s) is open to employees'.

As control variables the following are included: the respondent's age and job tenure, the age, size and legal form of the company.

Survey instrument - a structured questionnaire with 48 statements measuring variables and 6 items measuring control variables was developed. The questionnaire measured all items on a 4-point Likerttype scale, Respondents were asked to rate each statement on a scale of 1 to 4 (1 - strongly disagree, 4 strongly agree).

\section{Results and discussion}

The target group of the survey are people (employees and managers) employed in Latvian organizations. A link to the survey was sent to over 9,000 respondents through electronic address databases and social networks. The survey of respondents took place from February to March 2018. As a result, the survey was completed by 440 respondents $(n=440)$ who are employed in various sectors of the Latvian economy. Below the analysis of data about respondents is presented.

Occupation: $82 \%$ of respondents were found to be employees, $14 \%$ were managers or owners.

Age: $44 \%$ of the respondents are aged 51 and over, $20 \%$ are between the ages of 31 and 40, 19\% are between the ages of 41 and 50, and $16 \%$ are between the ages of 21 and 30 . Tenure: $57 \%$ of respondents have $21+$ years, $12 \%$ of $11-15$ years, $11 \%$ of $16-20$ years, $8 \%$ of 3 to 5 years, $7 \%$ of 6-10 years and $4 \%$ of respondents have less than 3 years of job experience. Age of the company: 64\% of the respondents were found to be in companies aged 16 and over, $15 \%$ of the respondents worked in companies between 5 and 10 years old, $12 \%$ of the respondents stated that they worked in companies of a lower age than 5 years and $9 \%$ of respondents represent companies aged 11-15 years old.

Company size: $31 \%$ of respondents work in companies with 51 to 250 employees, $26 \%$ in large organizations with over 251 employees, $24 \%$ in companies with 11 to 50 employees and $19 \%$ that they represent companies with up to 10 employees.

Legal form: It was found that $54 \%$ of respondents represent private companies, $39 \%$ of respondents represent state and municipal companies and the remaining $7 \%$ of respondents represent other companies.

Industry: It is found that $20 \%$ of respondents work in education, $11 \%$ in public administration and defence, $9 \%$ in construction, electricity, gas and heat, $8 \%$ in manufacturing and $7 \%$ in wholesale, with $6 \%$ of respondents working in the agriculture, forestry, fisheries and pharmaceutical and health sectors, 
5\% in arts and entertainment and finance, insurance and accounting, $4 \%$ in transport and logistics, $3 \%$ in IT and telecommunications and $2 \%$ in accommodation and catering services.

The data was gathered using self-reported measures and thus relies on self-reported measures, it may be subject to common method bias (CMB). A Hartman one-factor test was used to address common method bias (Podsakoff et al., 2012) and Factor 1 accounted for $47.2 \%$ of the variance, what is less than 50, thus indicating that CBM is unlikely to affect the data.

All scales showed acceptable to good internal consistency reliability - Cronbach's Alfa coefficients ranged between 0.879 to 0.976 (see Table 1) what is above 0.7 (Darren \& Mallery, 2003, lpp. 231). Multicollinearity test showed that variance inflation factor (VIF) range between 1.37 and 4.75 , thus it is below 10, with an average being 2.36; and Tolerance from 0.21 to 0.73 thus all values are above 0.2 , thus showing no multicollinearity (Field, 2018).

\begin{tabular}{|l}
\hline \multicolumn{2}{|l|}{ Table 1: Descriptive statistics and correlations } \\
\hline
\end{tabular}

Source: Author

Respondents are relatively positive about the implementation of the strategy (mean $=3.07$ ). The lowest valued independent variable is the process of change, followed by communication. Interestingly, despite the low rating of communication, the highest score is on the clarity of strategy and goals that could be considered as a result of communication.

Hierarchical regression results are presented in Table 2. Models 1 to Model 4 show the impact of control variables, while Model 5 and Model 6 show the effect of dependent variable on strategy realisation.

For industry factor dummy variables were created using Industry 2 (production) as a baseline. Model 1 shows that industry accounts for only $2 \%$ of strategy realisation $\left(\mathrm{R}^{2}=.019\right)$ and none of the industry dummies have significant effect. When ownership dummies are added, the $\mathrm{R}$ Square change is not significant (Model 2). The same refers to other control variables - the number of employees and the organisation's age (Model 3 and Model 4). The results in Table 2 indicate that control variables have no significant impact on the strategy realisation and accounts only for 3\% of strategy realisation.

Further, Model 5 shows the effect of four dependent variables (clarity of aims, change management, job satisfaction and communication) and accounts for an additional 63\% of strategy realisation $\left(\mathrm{R}^{2}\right.$ change $=.63^{* * *}$ and $\left.\mathrm{R}^{2}=.661\right)$. Charity of aims show the highest impact, followed by change management and communication as only the third factor $\left(\mathrm{B}=.41^{* * *} ; \mathrm{B}=.28^{* * *}\right.$ and $\left.\mathrm{B}=.13^{* * * *}\right)$. This is in line with Kruger \& Mama (2012) who pointed out the importance of clarity of strategic aims. Still these findings somewhat contradict Peng and Littlejohn (2001) who indicated communication as the main factor for strategy realisation. Thus $\mathrm{H} 1, \mathrm{H} 2$ and $\mathrm{H} 4$ are confirmed.

Interestingly, employee job satisfaction has no significant effect on strategy realisation and leads to the rejection of $\mathrm{H} 3$. The findings show that the importance of job satisfaction might be overestimated especially when it relates to the implementation and realisation of organisational strategy. Evidently more than just satisfaction is needed. Interestingly that respondents from Latvian organisation show quite high job satisfaction (mean $=3.11$; stdev $=0.6$ ) still the effect of this variable is insignificant.

Finally, Model 6 adds leadership factor which accounts for additional $9 \%$ of strategy realisation. The final model is able to explain $75 \%$ of the dependent variable thus the model has substantial predictive power. Leadership appears to have the strongest impact $(\mathrm{B}=.39 * * *)$. This result is in line with studies which have pointed out the critical role leaders paly in strategy implementation and realisation (e.g. Maditinos et al., 2014; Schaap, 2012; Hazarbassanova, 2016; Okumus, 2003) and confirms H5.

Items measured for the leadership variable show that leaders in Latvian organisation are good at strategic thinking, they take responsibility and on average possess leadership skills. Still they lack charisma, they 
do not recognise their mistakes and they are not always open to their employees. This can cause a lack of trust inside the organisation and thus hinder strategy implementation.

\begin{tabular}{|c|c|c|c|c|c|c|}
\hline Variables & Model 1 & Model 2 & Model 3 & Model 4 & Model 5 & Model 6 \\
\hline (Constant) & $3.075 * * *$ & $2.994 * * *$ & $2.941 * * *$ & $2.879 * * *$ & .254 & .071 \\
\hline Industry sector 1 & .293 & .301 & $.311 *$ & $.340^{*}$ & -.017 & -.040 \\
\hline Industry sector 3 & -.197 & -.208 & -.209 & -.202 & .023 & .056 \\
\hline Industry sector 4 & .055 & .067 & .064 & .076 & .019 & .027 \\
\hline Industry sector 5 & -.030 & .045 & .048 & .064 & -.014 & -.014 \\
\hline Ownership (state/municipality) & & -.039 & -.047 & -.035 & -.041 & .068 \\
\hline Ownership (private) & & .097 & .101 & .099 & .060 & $.142 *$ \\
\hline \begin{tabular}{|l|} 
Employees (11-50) \\
\end{tabular} & & & .063 & .082 & .113 & $.138 *$ \\
\hline Employees (51-250) & & & .064 & .087 & .114 & $137 * *$ \\
\hline Employees (251 and more) & & & .066 & .082 & $.157 *$ & $.209 * * *$ \\
\hline Organisations age (5-10 years) & & & & .076 & .048 & .054 \\
\hline Organisations age (11-15 years) & & & & .158 & -.006 & -.017 \\
\hline Organisations age (16 years and more) & & & & .004 & .006 & .055 \\
\hline Aim clarity & & & & & $.408 * * *$ & $.274 * * *$ \\
\hline Change management & & & & & $276 * * *$ & $.132 * * *$ \\
\hline Employee satisfaction & & & & & .070 & .021 \\
\hline Communication & & & & & $.129 * *$ & $.082 *$ \\
\hline Leadership & & & & & & $.385^{* * * *}$ \\
\hline Model Sig & .080 & .084 & .232 & .319 & .000 & .000 \\
\hline \begin{tabular}{|l|} 
R Square \\
\end{tabular} & .019 & .025 & .027 & .031 & .661 & .748 \\
\hline R Square Change & .019 & .006 & .001 & .005 & .630 & .087 \\
\hline F Change & 2.103 & 1.407 & .186 & .689 & 196.707 & 145.849 \\
\hline
\end{tabular}

\section{Conclusion}

The aim of this research was to identify the factors positively contributing to strategy implantation and realisation in Latvian organisations. Four out of five hypotheses were approved indicating that aim clarity, change management, communication, and leadership, have significant positive impact on strategy implementation and realisation. The hypothesis related to job satisfaction was rejected. This study has crystallized the role of the leader in the implementation of the strategy in Latvian companies and at the same time showed that job satisfaction has no significant impact on the implementation of the strategy. The second most important factor appears to be the clarity of the goals, which is undoubtedly related to the manager, because it is his responsibility to explain these goals and strategic direction.

However, this study has a number of limitations. The study has a correctional design and all variables, including strategy implementation, were evaluated based on respondents' ratings, which includes a degree of subjectivity. In addition, the study was conducted in Latvia and includes only Latvian organizations, and the number of factors included in the model are limited. Further research could be done by expanding the geographical coverage and including more independent variables in the model.

\section{References}

Aaltonen, P., \& Ikavalko, H. (2002). Implementing strategies succesfully. Integrated Manufacturing Systems, 13(6), 415-418.

Bolboli, S., \& Reiche, M. (2013). A model for sustainable business excellence: implementation and the roadmap. The TQM Journal, 25(4), 331-346.

Bryson, J., \& Bromiley, P. (1993). Critical factors affecting the planning and implementation of major projects. Strategic Management Journal, 14(2), 319-337.

Caune, J., \& Dzedons, A. (2009). Stratēǵiskā vadīšana. Rīga: Lidojošāā zivs. 
Darren, G., \& Mallery, P. (2003). SPSS for windows Step by Step. Pearson Education.

Dawson, P. (1997). In at the deep end: conducting processual research on organizational change. Scandinavian Journal of Management, 13(4), 389-405.

Dobni, C., Klassen, M., \& Sands, D. (2016). Getting to clarity: new ways to think about strategy. Journal of Business Strategy, 37(5), 12-21.

Edmonds, J. (2011). Managing successfull change. Industrial and Commercial Training, 43(6), 349353.

Field, A. (2018). Discovering Statistics using IBM SPSS Statistics. 5 ed. SAGE.

Greer, C. R., Lusch, R. F., \& Hitt, M. A. (2017). A Service perspective for Human Capital Respurces: A Critical Base for Strategy Implementation. Academy of Management Perspectives, 31(2), 137158.

Hazarbassanova, D. (2016). The value creation logic and the internationalisation of internet firms. Review of International Business and Strategy, 26(3), 349-370.

Hrebiniak, L. G. (2006). Obstacles to Effective Strategy Implementation. Organisational Dynamics, 35 , 12-31.

Hrebniak, L., \& Joyce, W. (1984). Implementing Strategy. Macmillan.

Charan, R., \& Colvin, G. (1999). Why CEOs fail. Time Incorporated, 69-79.

Katsioloudes, M. (2006). Strategic Management, Global Cultural Perspectives for Profit and NonProfit Organizations. Burlington: Elsevier Inc.

Kohtamaki, M., Kraus, S., Makela, M., \& Ronkko, M. (2012). The role of personnel commitment to strategy implementation and organizational learning within the relationship between strategic planning and company performance. International Journal of Enterpreneurial Behavior \& Research, 18(2), 159-178.

Koters, D., Kims, V., Maborna, R., Strebels, P., Čarans, R., Garvins, D., . . Džeksons, A. (2008). Pārmaiṇu vadība (Harvard Business Review izd.). Rīga: Lietišḳās informācijas dienests.

Kruger, C., \& Mama, M. (2012). Incorporating business strategy formulation with identity management strategy formulation. Information Management \& Computer Security, 20(3), 152-169.

Lertwattanapongchai, S., \& Swierczek, F. (2014). Assessing the change process of Lean Six Sigma: a case analysis:. International Journal of Lean Six Sigma, 5(4), 423-443.

Maditinos, D., Chatzoudes, D., \& Sarigiannidis, L. (2014). Factors affecting e-business successfull implementation. International Journal of Commerce and Management, 24(4), 300-320.

Miller, A., \& Dess, G. (1996). Strategic Management. International ed. 
Miller, S. (1997). Implementing strategic decisions: four key success factors. Organization Studies, 18(4), 577-602.

Mintzberg, H., Lampel, J., Quinn, J. B., \& Ghosal, S. (2002). The Strategy Process. Harlow: Pearson Education Limited.

Noble, C. H. (1999). The Eclectic Roots of Strategy Implementation Research. Journal of Busienss research, 45, 119-134.

Obeidat, B., Al-Hadidi, A., Tarhini, A., \& Masa'deh, R. (2017). Factors affecting strategy implementation: A case study of pharmaceutical companies in the middle east. Review of International Business and Strategy, 27(3), 386-408.

Obeidat, B., Al-Suradi, M., Masa'deh, R., \& Tarhini, A. (2016). The impact of knowledge management on innovation. Management Research review, 39(10).

Okumus, F. (2001). Towards a strategy implementation framework. International Journal of Contemporary Hospitality Management, 13(7), 327-338.

Okumus, F. (2003). A Framework to Implement Strategies in Organizations. Management Decision, 41(9), 871-882.

Parnell, J. (2010). Strategic Clarity, business strategy and performance. Journal of Strategic Management, 3(4), 304-324.

Peng, W., \& Littlejohn, D. (2001). Organizational communication and strategy implementation - a primary inquiry. International Journal of Contemporary Hospitality Management, 13(7), 360363.

Pfarrer, M. D., Devers, C. E., Corley, K., Cornelissen, J. P., Lange, D., Makadok, R., . . Weber, L. (2019). Introduction to Special Topic Forum: Sociocognitive Perspectives in Staretegic Mangement. Academy of Management Review, 44(4), 767-774.

Podsakoff, P. M., MacKenzie, S. B., \& Podsakoff, N. P. (2012). Sources of method bias in social science research and recommendations on how to control it. Annual Review of Psychology, 63(1), 539-569.

Schaap, I. (2012). Toward strategy implementation success: an empirical study of the role of the senior-level leaders in the Nevada gaming industry. UNLV Gaming Research\&Review Journal, 10(2), 2-16.

Schmelzer, C., \& Ohlsen, M. (1994). A data-based strategy implementing framework for companies in restaurant industry. International Journal of Hospitality Management, 13(4), 347-359.

Skivington, E., \& Daft, L. (1991). A study of organizational framework and process modalities for the implementation of business level strategic decisions. Journal of Management Studies, 28(1), 45-68. 
Sparrow, J. (2013). Creating and sustaining meaningful engagement: what managers need to develop in their five roles of engagers. Development and Learning in Organizations: An International Journal, 27(3), 8-10.

Succeeding with strategy: Key variables that influence implementation. (2018). Strategic direction, 34(1), 19-21.

Yin, N. (2018). The influencing outcomes of job engagement: an interpretation from the social exchange theory. International Journal of Productivity and Performance Management, 67(5), 873-889.

Аакер, Д. (2002). Стратегическое рыночное управление. Санкт-Петербург: Питер.

Томпсон-мл., А., \& Стрикленд, А. (2003). Стратегический менеджмент (изд. 12-е изд.). Москва, Санкт-Петербург, Киев: ИД Вильямс. 